\title{
SEKSISME EN FEMINISME IN TEOLOGIESE PERSPEKTIEF
}

\author{
Boekresensie met Kanttekeninge
}

Bouke Spoelstra.

Of 'n mens daarvan hou of nie, die feminisme dwing jou om vandag oor die vraagstuk standpunt in te neem. Beslissinge sal ook in die Gereformeerde leefwêreld geneem moet word waarin met die algemene twintigste eeuse kerklike musiek saamgespeel word om die "diskriminasie" teen die vrou op sterkte van haar seks "in die kerk" op te hef - of om andersins miskien op duidelike gronde 'n baie eensame standpunt in te neem. Ons verwys in dié verband na die volgende werk:

W. S. Vorster (ed) 1984: SEXISM AND FEMINISM IN THEOLOGICAL PERSPECTIVE (144 bll. Netjiese Hardeband. R11,50 + AVB). Die werk het verskyn by UNISA onder die reeks Miscellanea Congregalia.

Die agste simposium van die Instituut vir Teologiese Navorsing aan Unisa het in September 1984 vroue-referente hierdie aktuele en tipies twintigste eeuse onderwerp ter hand laat neem wat in nou verband met die stryd teen rassisme $(9,30)$ staan, want "both the oppression of women and black people is ontlogical; it has to do with who we are" (Goba, 30).

Dit val op dat die voordragte en response hoofsaaklik deur akademici van Unisa en slegs dr. Edwards van Rhodes Universiteit gelewer is. As sodanig en as produk van 'n kerklik onverbonde teologiese fakulteit, kan die referate redelik liberaal en onverantwoord aan konfessionele norme en uitgangspunte partikuliere gesigspunte as universele waarhede aandien. Daar skemer soms ook iets van aggressiwiteit teen kerklike standpunte, veral by Landman en Ackermann deur sonder dat dié standpunte toegelig of analiseer was. Die oorwegend Unisa-karakter van die besinning het dus die waarde dat daarmee eitnlik die gangbare standpunt in die wêreld en kringe van die WRK (79) binne 'n neutedop beskikbaar raak. Dit is die grootste waarde van die werk. Wat aangebied word, berus hoof raaklik op "vreemde" skrywers en boeke en bied min bronne wat "inheems" is.

Die onverbonde teologiese "Perspektief" gee natuurlik geen kritiese rekenskap van eie filosofiese bril en wetenskaplike uitgangspunte wat as aksiomas aanvaar word nie.

Die titel van die werk is ietwat misleidend. Die referaat van L G Baqwa, 'n prokureur van Johannesburg, oor "The legal position of women in South African society" is informatief, veral ook waar die reg die verskille tussen blanke, Mohammedaanse en swart huweliksopvattings moet reël, maar bied geen "teologiese perspektief" nie. Dieselfde geld tot op sekere hoogte vir die referate van dr. S. Viljoen (The role of women in society - a sociological perspective) en prof. L. C. Gerdes (The role of women in society - a psychological per. spective") Ten opsigte van twee van die drie oorgeblewe "teolo- 
giese" perspektiewe is dit 'n ope vraag wat met die begrip "teologiese perspektief" bedoel word wanneer die principium theologiae, die Skrif, nis as bron en norm geneem word nie. Bepaal die locus standi van die subjek, navorser of sy verbondenheid aan ' $n$ "teologiese" fakulteit of daarteenoor die spesefieke bronne en metodes van sy dissipline dat sy resultate "teologie" sal wees? Ironies genoeg, het die referate van Viljoen en Gerdes, miskien omdat hulle die openbaring van God as werklikheid fenomenologie benader, vir my 'n sterker "teologiese" perspektief as sommige ander referate gehad. Teologie moet tog "woorde" of "wetenskap oor God" wees, terwyl Ackermann vir Praktiese Teologie "the church" as bron vir teologie neem (62). Dit lyk asof hier die kerk die plek van die Skrif in die reformatoriese teologie geneem het.

Mej. Landman se referaat word in die respons "humorous" (30) genoem en mak in die geheel 'n tendensieuse, veralgemenende en betreklik oorsigtelike indruk waarin teologiese analise en besinning ontbreek. As oorsig oor eksponente van die feminisme is dit waardevol, veral waar sy skynbaar inval by die idee dat die Bybelse "patrargale" beeld van God as Vader afgebreek moet word en beoog word "to strip God of his masculine masks or patriarchy of its sexist contents" (4). Dit is opmerklik dat Gerdes weer wys dat hoe verder teruggegaan word in die geskiedenis, die vrou se rol skynbaar belangriker geag was (123-129).

In sy respons lig Goba tereg die kerngebrek van die referaat uit wanneer hy wys dat geen verantwoorde hermeneuse gebruik is nie en geen "value-free approach to biblical hermeneutics" moontlik is nie. Ewe belangrik in die respons is die opmerking dat die feminisme buite die kerk begin het en gaandeweg eers 'n impakt in kerklike kringe begin maak het" waardeur die "social forces" agter dic beweging deegliker aandag moes geniet het (33). Mej. Landman het skynbaar gegewe "models" uit die sekulêre wêreld as norme gencem $(19,20)$.

Die referaat van dr. Edwards bied 'n teologiese perspektief op die "hard" en "soft" feminisme en stuit op hulle "one-sided or partial" benadering waardeur sy 'n pleidooi vir "holistic feminism" loods (37). Hierin vind 'n mens aansluiting by aspekte wat Viljoen (116) en Gerdes (123v.) uit 'n minder ideologie en meer fenomenologiese werklikheidsanalise na vore bring, dr. E. se uitgangspunt in "feminism" as-isme (ideologie) kan moeilik teenoor "feminism" as sodanig, hard of sag, 'n alternatief bied. Die kritiek op die konflik model tussen man en vrou en eksegetiese getuieniミ oor Skrifplekke wat God en kerk (wat dan "male-dominated sou wees!) in die vroulike beskryf (43-48); is waardevol. Tereg wys sy dat 'n manlike bedienaar wat vroulike eienskappe mis, moet platval (51).

Vir D M Ackermann is teologie refleksie op inhoud van geloof en geloof in aksie as kommunikasie gebeure "within the church or in the name of the church" (62). Ekklesiologie as sodanig word dus normatief vir teologie geneem. Die kerk is vir haar "a democratic body in which no one person is greater than another - then why 
has the church over the ages assigned its key positions to men"? (63). Hieruit is duidelik dat haar kerkbegrip horisontaal en genootskaplik-sekulêr is en dat sy met die relasie van die kerk van Christus tot die sigbare kerk geen rekening hou nie en ook nie saam met Rome en Calvyn (Inst. IV $1 \mathrm{x}$-xii) sal aanvaar dat die amp of diens van die Woord aan die kerk voorafgaan en daarom nie onder kerklike jurisdiksie of plekbepaling val soos dié van 'n amptenaar in 'n genootskap nie.

Ackermann is skynbaar van oortuiging dat vervulling in die kerk neerkom op strewe na ampsbetrekkinge soos in enige "professie" (70) wat status en beloning meebring en dat die weerhouding van vroue 'n blote sosio-kulturele verskynsel is. Dat kerkwees primêr op Christenwees deur manne (ook diè wat nooit 'n amp beklee nie) en vroue neerkom (Ef. 4:11-16), geniet geen aandag nie. Inteen deel, op sterkte van een enkele vrou wat die Geref. kerk verlaat het, se getuienis maak sy uit dat Gereformeerde vroue (wat as "Dopper church" aangedui word) voel dat hulle nie gemis word nie, nie nodig is nie, hulle talente nie kan gee nie, behalwe wanneer hulle vir funksies moet koekbak. Die Geref. vrou is 'n "submissive, passive and slowly dying feminine member of the Reformed Church" bly (72). Sou ' $\mathrm{n}$ paar vroue in die amp dit wesenlik verander?

Afgesien van die onwetenskaplike afleiding op sterkte van een of ander bitter-bek vrou wat na posisie geaspireer het (waaroor dit tog nie by man of vrou mag gaan nie), kan die gevolg van 'n ekklesiologiese of kerksentriese teologie duidelik gesien word. Die kerk het in kontemporêre tyd die plek van Christus in die bepaling van kerklike dienste en ampte geneem. In 'n "demokratiese" liggaam is tog geen plek meer vir die ge ag van Christus nie.

\section{ENKELE KANTTEKENINGE}

By die lees van die verskillende referate en weergawe van die feministiese basis waarop die moderne "liberation" en "verwydering van "discrimination" ten behoewe van die vrou "in die kerk" geloods word, het die behoefte ontstaan om tog ook 'n paar kanttekeninge te maak wat nie juis op die doek nie, maar op die probleem betrekking het.

1. In die algemeen moet 'n mens seker vra wat die primêre motief vir die beweging is. Dit is moeilik om aan te neem dat so ' $n$ probleemstelling ' $n$ paar eeue gelede in 'n hoofsaaklik plattelandse of selfs meer pioniersmileu sou kon opkom. Toe was geen akademiese referate nodig om te bepaal wat ' $n$ man en 'n vrou hoeĩ te doen nie. Die vrou het waar nodig natuurlik die man na buite assisieer, terwyl die man natuurlik na binne $\mathrm{m}$ b t skoene mak, huisbou, vellebrei en slag na binne gehelp het. Die motief vir die feminisme op die eeu-oue kerklike terrein is mi onlosmaaklik verbonde aan die individualisme en natuurreg wat in die humanisme uit die bodem van Griekse heidense filosofie tydens die Rennaisiance opgekom het. Die beweging word dus primêr gestimuleer deur die reg van individu om vrylik op die professionele mark waar geld en status te verwerf is, te 
kompeteer. Tegelykertyd raak die beweging 'n sekere klas of kleiner persentasie vroue wat van hulle "gawes" bewus is en hulle wil laat geld op sterkte van hulle opleiding. Ek kan moeilik glo dat die oorgrote werkende vroue in fabrieke en besighede dit doen omdat hulle hulle self in daardie spesifieke rol wil verwesenlik. Die groot massa (en so ook massa mans) moet eenvoudig werk neem uit ekonomiese bestaansnoodsaak - of hulle daarvan hou of nie.

2. In die hantering van hierdie problematiek op kerklike erf sal baie noukeurig rekenskap gegee moet word van die filosofiese of aksiomatiese uitgangspunte waarmee die werklikheid analiseer en interpreteer word. Enige beskrywingspunt of rapport oor hierdie en verwante aangeleenthede behoort daarom voorop eers die basiese uitgangspunte en stellings op konfessionele, eksegestiese en selfs lewensbeskoulike vlak te maak. Dit spreek vanself dat iemand wat mense basies as kompeterende individue met individuele regte (soos demokratiese kiesreg) beskou en daarby nog man en vrou op sterkte van hulle seksverskil in atomistiese konflik beskou, totaal ander gevolgtrekkings gaan maak. Die referate bewys dit wanneer funksionele model $(39 \mathrm{v}, 66,108 \mathrm{v}, 129 \mathrm{v})$ teenoor die konflik benadering toegepas word. Man en vrou is op mekaar aangewese en vervul daarom aanvullende rolle. ' $n$ Mens wil byvoeg: die een verwesenlik homself nie sonder maar juis ook in en deur die ander in 'n twee-eenheid. Liefde en diens (Moltmann) bring ' $n$ ander begrip as konflik. 'n Man kan tog nie sonder en buite die vrou om vader word en wees nie, en omgekeerd. Dit is opmerklik dat feministe soos Halkes juis die teologies-sentrale idee van diens verwerp (66).

Daar mag tradisioneel vorme van "verslawing" van vroue aan mans op grond van die seksrol wees - my ervaring in die huise van my grootouers en ouers het eerder die indruk gewek dat wat ouma of moeder sê deur oupa en pa gedoen word. Is dit nie wat 1 Kor. $14: 35$ bedoel nie? Is die kerk nie juis in Christus ook 'n eenheid van baie nie (1 Kor. $10: 17 ; 12: 14)$ waarin die een in en deur die diens vorm en aan die ander vervul word nie? Geld dit nie ook dat diegene wat die amp vervul dit terwille van en ten behoewe van mans sowel as vroue met hulle saam 'n liggaam vorm doen nie?

3. Die soeke na oplossings deur "holistic feminism" en pleidooie van Viljoen en Gerdes om die konflik-model te vermy, laat dink dat daar juis vandag waar die individualisme kontekstueel die huwelik feitlik totaal oorbodig gemaak het, 'n nuwe besinning oor die Godbedoelde misterie (Ef. $5: 31,32$ ) van die twee-eenheid, man en vrou, nodig geword het. Kan die ongetroude vrou haar nie ook solider in die mede-gelowige man vind nie. Die Skrif self stel immers die huwelik in teologiese perspektief met die oog op Christus en sy hele gemeente en eienaardig genoeg stel die Skrif die sogenaamde "matedominated church" as vrou en bruid voor!

4. Daar sal baie duidelik besin moet word oor kernbegrippe soos kerk, amp, diens, regeer ens. Watter plek beklee die kerk waarvan in die 12 Artikels belydenis gedoen word in die sigbare fenomeen 
wat vandag "kerk" (en meervoud) genoem word en watter rol speel die "amp" daarin? Word die rol t.o.v. die liggaam van Christus op sterkte van wat Christus wil (volgens Skrif en tradisie) of op grond van die demokratiese kerkliggaam volgens kontemporêre wil van die "lidmate" gestruktureer? Is die amp sinoniem met die atatus, eer, regering en heers van amptenare op grond van posisie in ' $n$ sosiale struktuur? Kortom, behoort die "amp" en bepaling van wat kerk en amp is by die "lidmate" of by die Hoof, Christus, tuis?

5. Op die simposium het reeds herhaaldelik duidelik geword dat daar duidelik hermeneutiese uitgangspunte as uitgangspunte neergelê moet word. Daar moet duidelik gesê word wat die Bybel is en of dit gesag dra (Vgl. Scheffler, 85). Die vertrekpunt in die "kerk" bring 'n totaal ander "teologie" na vore as wanneer die openbaring van God as uitgangspunt geneem word. Onbewus gly Bybelge. lowige teoloë wat die "kerk" as norm neem in kontekstuele opvattings in met begrippe "kiesreg", stemreg, demokrasie ens. Kerksentrisme open 'n deur vir die kerk as mense om hulle self te verabsoluteer." Teologie word 'n wetenskap oor die refleksie van mense as "kerk".

Dit val op dat in die Rapport oor die sogenaamde "kiesreg" van die vrou voor Sinode 1985 die woorde "in die kerk" seker vyftien maal op 'n paar bladsye gebruik word. Ek sou as norm liewer nie die "kerk" nie, maar die Skrif, konfessie of Christus wou neem, al sou sommige my as "fundamentalisties" etiketteer. Daarmee is die bron minstens objektief geneem en het so 'n "teologie" net so veel reg van bestaan as die moderne subjektiewe refleksie oor mense se ervaring van godsdiens. Die kerk is of 'n ding, 'n instituut, 'n genootskap waar die "lidmaat" regte het omdat dit 'n "democratic body" is - of die kerk is verloste mense vir wie Christus bedieninge ingestel het. Die wese van die bediening is juis diakonia, diens (Joh. 13) wat die pous as servus servorum wou wees tot heerskappy en luister vervorm het. Dit gebeur wanneer die ampsdraer op grond van sy ampsaanstelling gesag uitoefen, terwyl Christus dienaars geroep het om sy Woord aan die kerk (mense) te bedien en so sy kerk te vergader (Heid Kat S 21). Die simposium van Unisa het gefokus op die vraag hoe kerke die dienste vir mans teen vroue struktureer $(25,51,79,87)$, terwyl daar 'n vraag onbeantwoord bly: hoe Christus die ampte struktureer het, 'n vraag wat seker ook vir die pous (65) se onwil om in pas met die 20ste eeu te val, verantwoordelik is.

6. Die vraag of vroue soos mans "stemreg" het "in die kerk" het in en na Sinode 1985 nogal heelwat aandag getrek - ongelukkig meer op formele en selfs kollegialistiese struktuurgronde, as of gesag tot sekere beslissings limitatief by sekere strukture tuishoort.

Ek het selfs meegedoen om aan te kondig dat "stembriewe aan alle stemgeregtigde lidmate van die gemeente wat nie onder sensuur is nie" uitgedeel word. Daarvolgens het mans "stemreg", altans op die klank van die afkondiging af. Net so klink dit seker ook erg diskriminerend teenoor die vrou. Dit word te meer onstigtelik wanneer vroue deur die moderne feminisme sensitief vir die "diskriminasie" in 'n kerk wat vir hulle 'n genootskap is, gemaak word. 
Ek wil kategories stel dat na my mening geen mens, man of vrou, "stemreg" in die kerk het nie. Daar is gevalle waar die gemeente adviserend en aanwysend 'n plig of verantwoordelikheid in die roeping tot die amp vervul het (Hand. $6: 2-6 ; 14: 23$ ), maar as 'n "reg" (en natuurreg in die sin van die Rasionalisme van Rousseau se Contrat 1'Social was dit sekerlik nie. Ons kerklike "stem"uitoefening volg vandag die sekulêre stempatroon. Ek glo die prosedure is tydsgebruikte beinvloed en bepaal. Hoewel ek my op dic punt nie kon op hoogte stel nie, wil ek waag om te beweer dat in die NT-tyd en selfs in terme van die begrip "meerderheid van stemme" (art. 31 Dordse Kerkorde) nie ' $n$ blote tel van individuele stemme bedoel was nie - en allermins op 'n tweetal wat vooraf vasgestel was. Waarskynlik het uitsoek van manne en "kies" in daardie tyd baie meer op 'n keuse deur konsensus as blote numeriese meerderheid bedoel. Tot vandag toe kan een dogtertjie van twaalf jaar wat haar stem oor die swak gedrag of karakter van een ampsdraer uitbring, 'n hele verkiesing ongeldig maak. Is dit nie stemreg nie?

Wat op die spel is daarom vrae of die kerk 'n demokratiese lig. gaam met gelyke regte aan sy "lidmate" is en of dit 'n organiese liggaam is waarin sekere lede funksies ter wille van ander voel en waarin daar 'n gemeenskap, koinonia, kragtens een-wees in Christus (eerder as een in kerkorganisasie), heers. Dit het my dikwels opgeval hoe die argumente vir die sogenaamde kiesreg die grofste gemeenskapsontbindende inslag openbaar. So hoor 'n mens dat 'n vrou vra: Waarom mag daardie bog snuiter wat pas belydenis gedoen het stem, terwyl ek, so en so 'n begaafde vrou, uitgesluit is? In so 'n agtergrond lyk dit my asof die wese van die kerk ons verplig om of die sogenaamde "stemmery" te staak en in plaas van 'n reeds uitgestemde tweetal maar altyd 'n eental vir approbasie voor te lê - of baie duideliker die koinonia-karakter van die kerk, die solariteit van die gelowiges te beklemtoon.

Moet beroeping van predikante ook nie eerder uit 'n groslys geskied wat uit die gesinne ter tafel gelê is sonder dat die kerkraa'l daaroor meer as ordenend gaan handel? So lei besinning oor een vraag na 'n ander. 